\title{
FROM EDIBLE TO USEFUL MUSHROOMS - AN ATTEMPT FOR THE NEW ECONOMICAL ASSESSMENT OF LARGE FUNGI
}

\author{
J. I. LELLEY
}

Institute for Mushroom Research, GAMU Ltd., Krefeld, Germany

\begin{abstract}
According to the stand of the modern applied mycological research the most commonly used term "edible mushroom" does not express all significant aspects large fungi can be used for. Additionally to bioconversion for food and animal feed production there are at least three other fields where large fungi may also get economical relevance: for establishing of ectomycorrhiza, for medical application and for soil decontamination including environmental engineering. This new situation justifies the introduction of a new, allembracing designation for large fungi. The term "useful mushroom" will be suggested. The various options of the use of mushrooms will be introduced and briefly discussed in this paper.
\end{abstract}

\section{Introduction}

Edible mushroom cultivation has greatly increased worldwide in the last 15 years. Not only has the production volume risen dramatically, but the focus of edible mushroom cultivation has altered as far as range is concerned. Also noteworthy is the geographical shift in production from the West (Europe, North America) to the East (East Asia). At the same time the significance of the white mushroom (Agaricus bisporus) has declined appreciably.

The value of worldwide edible mushroom sales was some $\$ 9.8$ billion in 1994 [6]. However, we can still expect the consumption and production of edible mushrooms to grow further in the future. Extensive, as yet untapped consumer potential exists in the eastern central European countries, the Baltic states, Russia, as well as in the Arab nations, Africa and Latin America. The cultivation and consumption of mushrooms is set to rise continually in these regions. The reasons for the expansion in production will differ, however, from country to country. But they can be summarized as follows

- Worldwide general change in eating habits

- Consumers' desire for higher-grade foods as a consequence of higher standards of living

JAN I. LELLEY

Institute for Mushroom Research, GAMU Ltd. Hüttenallee 237 c, D-47800 Krefeld, Germany 
- In some parts of the world, the necessity to ensure an adequate supply of food for the population

- The variety of available options for edible mushroom cultivation and the exploitation of cultivation methods matched to practically all conditions

- Efforts to obtain foreign currency by exporting mushrooms and/or mushroom products

We could thus be content and simply await future developments. On the other hand, the outlook for mushroom growers in the industrialized nations is gloomy. The prospects for creating wealth are restricted by the problems of general economic conditions in the European Union (increasing costs, stagnating prices, more stringent regulations and many other factors), predatory competition in the $\mathrm{EC}$ and competitive pressure from eastern central Europe and Asia.

It is therefore an appropriate time to take stock of mushroom cultivation and the opportunities it offers and to seek ways in which the industry can succeed by way of crisis management. The practices of mushroom cultivation and, of course, research, have to be redefined. We must carefully think about the feasible prospects of the sector and provide researchers with fresh impetus.

In this paper we would like to engender and to continue a clarifying discussion involving as many interested parties as possible.

\section{Definition of "useful mushroom"}

The first thing to do is to demarcate the principal area of interest and describe the object of discussion: the mushroom or mushrooms.

Throughout the world mushroom cultivation involves only large mushrooms; that is to say, those we commonly call "mushrooms", also referred to as macromycetes and macrofungi. The framework in which mushroom growers operate is determined merely by the size of the mushrooms, not by their type or any other criteria. follows:

The large mushrooms cultivated by mushroom growers worldwide are defined as

The mushroom is a macrofungus with a distinctive fruiting body and large enough to be seen with the naked eye and to be picked by hand [7].

Chang [5] extends this definition as follows: Thus, mushrooms need not be Basidiomycetes, nor aerial, nor fleshy, nor edible. Mushrooms can be Ascomycetes, growing underground, having a non-fleshy texture and need not be edible.

According to Chang, therefore, the macrofungus category does not constitute a systematic entity. Rather, the definition crosses boundaries, while complying with certain morphological characteristics. Moreover, it focuses on the objective of economic utilization. On the basis of his definition, Chang [5] forms four categories of macrofungus:

- Those, which are fleshy and good to eat: edible mushrooms (e.g. Agaricus bisporus) 
- Those, which can be used in medicine: medicinal mushrooms (e.g. Ganoderma lucidum)

- Those which are poisonous (e.g. Amanita phalloides)

- Those whose attributes are as yet entirely or largely undefined

Chang's definition of large mushrooms is acceptable and can therefore be used as the basis for further observations. His categorization into four groups is, however, not very useful. It completely ignores some important aspects and instead relates specifically to the situation in East Asia and the demands made on large mushrooms in this region.

To do justice to the outstanding economic role they play in the industrialized nations, we have to take a more differentiated look at large mushrooms and describe them more comprehensively. To this end, however, we must detach ourselves as much as possible from existing notions and also turn our attention to new unconventional fields of application. Without doubt, the way for mushroom cultivators in the industrialized nations to overcome the present crisis lies in the answer to the following question: For what purposes other than consumption could large mushrooms be produced and utilized?

The exploitation of additional applications justifies the introduction of a new, allembracing designation. My suggestion is based on a familiar and generally recognized technical term in the fields of botany and zoology. Plants and animals of which man makes various use in agriculture, forestry and other sectors of the economy are called "productive" or "useful". In line with this designation, it would be purposeful to introduce a definition of useful mushroom(s):

Useful mushrooms are thus all large mushrooms used by man wholly or in part (mycelium, fruiting body or both); that is to say, all cultivated mushrooms and wild mushrooms of economic use.

The term most commonly used until now, edible mushroom, is restrictive and incomplete, even if many large mushrooms are produced primarily for human consumption. Eating mushrooms is, however, only one of several significant potential uses. Depending on the species, they can also be used in medicine, environmental engineering and ecosystem protection. "Useful mushroom" thus opens up new dimensions. We must investigate these before we can give answers to compelling questions of the future.

\section{Worldwide potential applications of large mushrooms}

At present there are four relevant options for using large mushrooms:

\section{Bioconversion for food and animal feed production}

The most significant characteristic of mushrooms is their ability to convert the enormous quantities of cellulose and lignin that make up the bulk of the vegetable biomass. This attribute is used worldwide to produce a mushroom biomass with a high physiological food value from agricultural and woodland waste that is often unsuitable for further use. Concerning the food value the most important substances in mushroom 
biomass are amino acids (also essential amino acids), carbohydrates, vitamins (thiamin, riboflavin, niacin, folic acid, pantothenic acid, calciferol) as well as minerals (potassium, phosphor, iron).

It is worth to take a close look at this process. Plant growing produces food by deriving organic material from inorganic resources. In livestock farming, high-grade biomass is converted from one form into another with an input:output ratio of at least $3: 1$, even with modern production methods. In addition, both activities give rise to large quantities of waste. Mushroom cultivation is exceptional, however, in that it produces high quality food by degrading organic materials. Mushroom cultivators use and recycle the waste and residual materials generated by crop and livestock farmers. They contribute a great deal to waste avoidance and disposal.

At present mushrooms are still produced mostly for human consumption in both the western and the eastern hemispheres. It is therefore unnecessary to describe this method of use in greater detail here.

The use of large mushrooms to produce animal feed, on the other hand, has to be explained briefly. The ability of some large mushrooms (white rot fungi) to degrade lignin in lignocellulosic material can directly and substantially enhance the value of the plant as a source of dietary energy. The partial breakdown of the lignin component by the mushrooms allows the intestinal flora to make better use of cellulose. Ruminants in particular can benefit from this advantage $[9,19,33,34,35]$.

\section{Establishing of mycorrhiza}

The symbiotic relationship between mushrooms and higher plant forms is referred to worldwide as mycorrhiza (mushroom root) after Frank [12]. Its most common form, which occurs on trees in the forests of central Europe, is ectotrophic mycorrhiza. From a morphological viewpoint, it is regarded as a unified organ [12].

Ectotrophic mycorrhiza result primarily from basidiomycetes and some ascomycetes. Among the ectotrophic mycorrhizal fungi are well-known forest mushrooms and some highly valued edible mushrooms, such as truffles, Boletus edulis and chanterelles. Most of the capable mycorrhizal fungi, however, are of no value from the layman's viewpoint and largely unknown: Paxillus involutus, Scleroderma vulgaris (common earth ball), Pisolithus tinctorius and others.

The physiological benefits of the symbiosis between tree and mushroom are very important for the tree. It allows the tree to transpire if the ground is dry and promotes more efficient photosynthesis. The hyphae of the mushroom colonize the soil much faster than the tree's roots. This can increase the nutrient and water-absorbing surface area as much as 1,000-fold and also enlarge the exploited soil volume. The absorption of soil nutrients, including those that are present in a form that plants cannot exploit, is intensified. The mycorrhizal fungi produce enzymes and organic acids, which increase the solubility of the minerals in the soil. In addition, the mushrooms keep company with nitrogen-fixing anaerobic bacteria. The supply of nitrogen to the tree is ensured by this "hypersymbiosis" and the absorption of mineral nitrogen [10, 15, 20, 23, 27, 30, 31].

The mycorrhizal fungus gives the tree very substantial protection by diverse mechanisms [4, 22, 26, 29, 36]. It also has a positive effect on the roots' environment, the mycorrhizosphere, which is distinct from the rhizosphere. The mycorrhizosphere has been 
found to contain more water-resistant soil aggregates, which increase the soil's ability to retain water and improve its aeration [2].

We are now aware of the scientific and technical preconditions for the specific application of mycorrhizal fungi in forestry. We anticipate the worldwide onset of commercial, large-scale production of a mycorrhizal fungal inoculum. According to Becker [1], this inoculum could give rise to a considerable market in Germany. Assuming 10 million hectares of woodland in Germany, an average rotational period of 100 years and $50 \%$ artificial regeneration, and given an average of 5,000 plants per hectare, the annual demand is 250 million plants. If each of these plants is worth DM 1 on average and the additional cost of producing mycodendrons from them is $10 \%$, this use of large mushrooms could generate annual turnover of some DM 25 million in Germany alone [1].

\section{Medicinal applications}

Some of the early botanists (Hieronymus Bock, Adamus Lonicerus, Peter Melius) who wrote books on herbs which were well-known in Europe in the 16th and 17th centuries recommended large mushrooms for medical applications. Some of these, such as the paste produced from the spores of the Lycoperdon genus of fungi, are still mentioned today in homeopathic literature. Measured against the significance of medicinal mushrooms in East Asia, however, their use in the West has been very modest.

In East Asia some large mushrooms have been valued for centuries as effective remedies. During the Ming Dynasty (1368-1644), Whu Shui was already praising shiitake (Lentinula edodes) as an elixir of life that cured colds, stimulated the circulation and built up stamina. Various preparations derived from the jew's-ear (Auricularia polytricha) have been recommended to treat weakness after childbirth, blocked blood vessels and numbness.

The tonic qualities of mushrooms are still highly regarded in East Asia [14]. In China, Japan and Korea, for example, the current annual sales of drugs made from Lentinus edodes, Schizophyllum commune, Coriolus versicolor and others are estimated at $\$ 3.6$ billion [6].

The objective of traditional chinese medicine (TCM) is to support and promote positive factors in the patient and to strengthen the body's immune system in order to prevent disease. Besides, other activities, research into and testing of new antitumor drugs follow this basic principle. The aim is to find biological response modifiers (BRM), substances that promote the positive factors and eliminate the negative factors from the human body. These include interferon, interleukin-2 and lentinan. In addition to surgery, chemotherapy and radiotherapy, BRM have become the fourth principal form of conventional cancer treatment [32].

Several experts believe that the medical fraternity could regard large mushrooms much more favorably in Germany in the future $[11,21,24,25,28]$. The natural remedy industry has already started to take an interest in large mushrooms, and customers react very positively to the notion that many large mushrooms could be used as natural remedies.

The further development of this application could therefore spawn a market for medical mushrooms in Germany in the foreseeable future. 


\section{Soil decontamination, environmental engineering}

Bumpus and Aust [3] and other authors stated that Phanerochaeta chrysosporium, a white rot fungus, is able to break down a large number of structurally different organic substances. These include many pollutants that are difficult to degrade. They concluded that this singular biodegrading capability was linked to the mushroom's lignin-degrading system and was unspecific and extracellular in nature. In laboratory experiments, Bumpus and Aust [3] succeeded in breaking down several aromatic compounds (containing a benzene skeleton), such as vanillic acid, and even lindane and DDT.

As far as quantity is concerned, the principal naturally occurring substance that consists mainly of benzene rings is lignin. It is a component of nearly all parts of plants; wood, for instance, contains an average of $30 \%$ lignin. As stated above, the enzymes of white rot fungi enable them to decompose and mineralize lignin in particular. The enzymes are highly non-specific and effective with practically all aromatic compounds [16].

Experiments concerning the practical use of this ability of white rot fungi - to decompose hazardous aromatic compounds in the soil and air - have focused primarily on the easily cultivated oyster mushroom (Pleurotus ostreatus). First of all, an active mushroom substrate that remains stable for a long time was produced from cereal straw.

After colonization by the oyster mushroom mycelium, the straw is mixed with contaminated soil according to a certain volume content. The ecophysiological parameters are subsequently controlled so that the mushroom mycelium remains active for as long as possible. The hazardous substances in the soil are then decomposed together with the straw substrate. Contaminated air passed through a layer of this type of substrate can also be substantially cleaned if the rate of flow and layer thickness are matched to one another [16-18].

Although very limited research has been conducted so far into this potential application, which is highly topical from an environmental policy viewpoint, large-scale commercial projects have already been implemented in Germany. Noteworthy in this context is an installation near Hamburg, where several thousand tons of tar-contaminated soil have been cleaned. Here again, the mycelium of the oyster mushroom that was used had been cultivated on cereal straw. Several hundred tons of oyster mushroom substrate was used. The average contamination of more than $180 \mathrm{mg}$ PCAH (polycyclic aromatic hydrocarbons) per kilogram dry soil was reduced to below $40 \mathrm{mg}$ within 16 months.

\section{The consequences for research and practice}

Both researchers and practitioners have to respond to the new outlook on mushroom cultivation as described above. At the same time, all the energies and capacities of the large mushroom research sector must be brought together. Many species of mushroom have two or even three potential applications (food production and naturopathy or food production, environmental engineering and animal feed production). Moreover, many similarities and overlaps exist as regards the laboratory and research work into the various uses of large mushrooms. Many years of experience have shown 
that close cooperation between those working in research into useful mushrooms, notwithstanding their diverse objectives, is very stimulating and beneficial to all parties.

Scientists must also learn to fill in the considerable gaps that exist in the general knowledge of large mushrooms and mycology in general; the public, politicians, public authorities and association officials all have to be educated. It is a telling observation that most people do not have any notion of what a "medicinal mushroom" is. Only very few spontaneously make the rather obvious - association with medicinal plants. Most people think that mushrooms are either edible or poisonous and otherwise uninteresting.

Mycologists themselves are, regrettably, partly to blame for this lack of understanding. Thus far they have been unable to distinguish themselves from botanists and establish mycology as an independent field. Despite the abundance of pertinent facts, they have even failed to assert the overdue distinction between plants and mushrooms and have not constituted a discipline dedicated exclusively to mushrooms. This diffuse approach has caused people to classify edible mushrooms as vegetables and to teach production methods as a subject for vegetable growers, if at all. Misleading concepts such as "plant protection in mushroom cultivation" have been coined in this context. This lack of regard for mycology probably explains the general unwillingness of foresters to accept that symbiosis can exist between the fragile mushroom and the mighty tree

The scientific reputation and evaluation of large mushroom research is still so slight in Germany as well as in Hungary that not a single chair or principal scientific post exists in the universities and specialist colleges of further education. At the same time, several professorships for Tibetan Studies have been created at German universities. A dramatic change has to be accomplished on a broad front as soon as possible.

The situation outlined above foreshadows far-reaching consequences for practical mushroom cultivation. Growers will have to be far more flexible, prepared to cultivate several mushroom species and able to adjust the focus of their activities according to changing situations. Process engineers are required to standardize cultivation methods as far as possible and to elaborate unified methods for different species. This will make it easier for cultivators to switch production from one species to another or to grow several species at the same time, depending on demand.

The scope embraced by the term "mushroom cultivation" must be broadened in the future. Mushroom growers will no longer be producing only edible mushrooms. Since the potential applications of large mushrooms are not restricted to their fruiting bodies, but also generate demand for large quantities of substrate colonized by mycelia, for the purposes of soil decontamination or the establishment of mycorrhiza, for example, some enterprises could exist alongside fruiting body growers and produce "only" mycelia.

Well-established structures will inevitably change and the industry will have to set itself new objectives and goals. As well as exploiting its opportunities in the food sector, it will have to develop and utilize the various options available to large mushrooms in various other branches of economic activity.

In addition, the mushroom industry must step up its commitment to research with more financial investment or by subsidizing the work of research institutes. The utilization of useful mushrooms in the new fields mentioned above has so far been hampered or held back principally by a dearth of scientific groundwork. If a lack of support causes this situation to persist, the mushroom industry will be doing itself a disservice. 


\section{REFERENCES}

1. Becker,A.: Perspektiven für den gezielten Mykorrhizapilz-Einsatz in der Forstwirtschaft. Forst und Holz 49(7), 182-185 (1994).

2. Borchers,S.L., Perry,D.A.: Growth and ectomycorrhiza formation of Douglas-fir seedlings grown in soils collected at different distances from pioneering hardwoods in southwest Oregon clear-cuts. Can J For Res 20, 712-721 (1990).

3. Bumpus,J.A., Aust, S.D.: Biodegradation of environmental pollutants by the white rot fungus Phanerochaeta chrysosporium: Involvement of the lignin degrading system. Bio Essays 6(4), 166-170 (1987).

4. Chakravarty,P., Unestam,T.: Differential influence of ectomycorrhizae on plant growth and disease resistance in Pinus silvestris seedlings. J Phytopathol 120, 104-120 (1987).

5. Chang, S.T.: Mushroom and mushroom biology. In Chang,S.T., Buswell,J.A., Miles,P.G. (eds): Genetics and Breeding of Edible Mushrooms. Gordon and Breach, Amsterdam. 1993. pp. 1-13.

6. Chang, S.T.: A Global Strategy for Mushroom Cultivation - A Challenge of a "Non-Green Revolution". The Proceedings of 98' Nanjing International Symposium on Science and Cultivation of Mushrooms. 1998. pp. $5-15$.

7. Chang,S.T., Miles,P.G.: Mushroom biology - a new discipline. The Mycologist 6, 64-65 (1992).

8. Delcaire,J.R.: Evolution de la consommation des champignons comestibles dans le monde au cours de la période 1977-1982. Mushroom Sci 10(2), 863-893 (1979).

9. Domsch,K.H., Zadrazil,F.: Biotechnological approaches to the development of microbiological foodstuff and fodder from unconventional raw materials. Animal Research and Development 16, 51-59 (1982).

10. Dosskey,M.G., Lindermann,R.G., Boersman,L.: Carbon-sink stimulation of photosynthesis in Douglas fir seedlings by some ectomycorrhizas. New Phytol 115, 269-274 (1990).

11. Eisenhut,R., Fritz,D.: Medizinisch nutzbare Wirkungen und Inhaltsstoffe von Speisepilzen. Gartenbauwissenschaft 56(6), 266-270 (1991).

12. Frank,B.: Über die auf Wurzelsymbiose beruhende Ernährung gewisser Bäume durch unterirdische Pilze. Ber Dt Bot Ges 10, 577-583 (1885).

13. Ginterova,A:: Pleurotus in modern agricultural production. Mushroom Sci 12(2), 99-107 (1989).

14. Hanssen,H.-P, Schadler,M.: Pilze als Volksheilmittel in der chinesischen Medizin. Dt Apotheker Zeitung 122(37), 1844-1848 (1982).

15. Harley,J.L., Smith,S.E.: Mycorrhizal Symbiosis. Academic Press, London. 1983.

16. Hüttermann,A., Loske,D., Braun-Lüllemann,A., Majcherczyk,A.: Der Einsatz von Weißfäulepilzen bei der Sanierung kontaminierter Böden und als Biofilter. BioEngineering 4(3), 156-160 (1988).

17. Hüttermann,A., Trojanowski,J., Loske,D.: Verfahren zum Abbau schwer abbaubarer Aromaten in kontaminierten Boden bzw. Deponiestoffen mit Mikroorganismen. Patentschrift, DE 3731816-C1 1988.

18. Hüttermann,A., Majcherczyk,A., Zadrazil,F.: Verfahren zum Dekontaminieren von sauerstoffhaltigen Gasen, insbesondere von Abgasen. Patentschrift, DE 3807033-C2 1990.

19. Lelley,J.: Möglichkeiten der Mykofutterherstellung durch Verwertung lignocellulosehaltiger landwirtschaftlicher Reststoffe. Ubers Tierernahrung 12, 63-84 (1984).

20. Lelley,J.: Einsatz von Mykorrhizapilzen in der Land- und Forstwirtschaft. Okologie \& Landbau. 25(1), 3338 (1997).

21. Lelley,J.: Die Heilkraft der Pilze - Gesund durch Mykotherapie. Econ Verlag, Düsseldorf. 1997.

22. Lelley,J., Schmitz,D.: Die Mykorrhiza - Lebensgemeinschaft zwischen Pflanzen und Pilzen. Praktische Nutzung in der Forstwirtschaft. Selbstverlag, Krefeld. 1994.

23. Li,C.-Y., Castellano,M.A.: Azospirillum isolated from within sporocarps of the mycorrhizal fungi Hebeloma crustuliniforme, Laccaria laccata and Rhizopogon vinicolor. Trans Br Mycol Soc 88, 563-566 (1987).

24. Lindequist,U., Teuscher,E., Narbe,G.: Neue Wirkstoffe aus Basidiomyceten. Z für Phytotherapie 11, 139149 (1990). 
25. Liu,G-T.: Pharmacology and clinical uses of Ganoderma. In Chang,S.T., Buswell,J.A., Chiu,S.-W. (eds): Mushroom Biology and Mushroom Products. The Chinese University Press, Hong Kong. 1993. pp. 267273.

26. Marx,D.H.: The influence of ectotrophic mycorrhizal fungi on the resistance of pine roots to pathogenic infections. I. Antagonism of mycorrhizal fungi to root pathogenic fungi and soil bacteria. Phytopathology 59, 153-163 (1969).

27. Melin,E., Nilsson,H.: Transfer of radioactive phosphorus to pine seedlings by means of mycorrhizal hyphae. Physiol Plant 3, 88-92 (1950).

28. Molitoris,H-P.: Pilze als Heilpflanzen in Vergangenheit, Gegenwart und Zukunft. Forum Mikrobiologie 1(1), 11-18 (1978)

29. Moser,M.: Mikrobiologie des Bodens und Forstwirtschaft. Mittl Forstlichen Bundesversuchsanstalt 60, 683689 (1963).

30. O’Dell,T.E., Castellano,M.A., Trappe,J. M.: Biology and Application of Ectomycorrhizal Fungi. In Blaine Metting,J. (ed.): Soil Microbial Ecology. Marcel Dekker, New York. 1993. pp. 379-416.

31. Varna,A., Hock,B. (eds): Mycorrhiza, Structure, Function, Molecular Biology and Biotechnology. Springer Verlag, Berlin, Heildelberg etc. 1995.

32. Yang,Q.Y., Hu,Y.J., Li,X.Y., Yang,S.X., Liu,J.X., Liu,T.F., Xu,G.M., Liao,M.L.: A New Biological Response Modifier - PSP. In Chang,S.T., Buswell,J.A., Chiu,S.-W. (eds): Mushroom Biology and Mushroom Products. The Chinese University Press, Hong Kong. 1993. pp. 247-259.

33. Zadrazil,F.: Die Umwandlung von Stroh in Tierfutter durch hohere Pilze. Kali-Briefe 14(11), 759-764 (1979).

34. Zadrazil,F.: Screening of fungi for lignin decomposition and conversion of straw into feed. Angew Bot 59, 433-452 (1985).

35. Zadrazil,F.: Straw Decomposition by Fungi (Basidiomycetes) with its Subsequent Use as Edible Mushroom, Feed Supplement or Compost. The Proceedings of 98' Nanjing International Symposium on Science and Cultivation of Mushrooms. 1998. p. 157.

36. Zak,B.: Role of mycorrhizae in root disease. Ann Rev of Phytopathology 2, 377-392 (1964). 